\title{
Text Forming Potentials of Verbs
}

\author{
Khatira Suleymanova ${ }^{1}$ \\ ${ }^{1}$ Azerbaijan University of Languages, Baku, Azerbaijan \\ Correspondence: Khatira Suleymanova, Azerbaijan University of Languages, Baku, Azerbaijan. E-mail: \\ khatira.suleymanova@mail.ru
}

Received: May 30, 2015 Accepted: June 16, 2015 Online Published: September 29, 2015

doi:10.5539/ijel.v5n5p153 URL: http://dx.doi.org/10.5539/ijel.v5n5p153

\begin{abstract}
The article explores text forming potentials of verbs, considered on the materials of the English, Russian and Azerbaijani languages. Verb differs from other parts of speech as to the many numbers of categories, as to the richness of lexico-semantic, morphological-syntactical, phraseological and phonetical peculiarities. Verbs play a special role in forming combinations with other words in the sentence and in the text, during the consideration of which their valency is investigated as well. Analyzing the examples taken from the literary fictions on the materials of the three languages, we specify certain types of texts in which verbs govern all the types of utterances being the main, organizing elements of sentences.
\end{abstract}

In the article we come to the conclusion that valency of verbs, i.e., its ability of forming combinations with other words is the ground for the successful act of communication.

Keywords: verb, text, valency, communicative strategy, invertion

\section{Introduction}

As it is known, the majority of grammatical categories are the brightest example to the fact that verbs in the process of communication play a great role, which can be considered as the basis for the constructive and semantic element of a sentence. The more expressive the verbs are, the brighter is our imagination on the subject of speech. Depending on what we are going to express, who we are communicating with, adequate choice of verbs in speech takes place. But, naturally not only the verb is sufficient enough in the realization of speech act. Just as a result of combination of verbs with other words in a sentence this or that strategy is realized. Just by this arises the urgent necessity of investigating its valency, which should be carried out in the coorelated texts. Verbs do not only name concrete acts, but also they intend to determine the sense of the whole situation. Grammatical category of verbs is not only used in forming a text, but they also make great influence on the sense of sentence and on the type of texts.

\section{Survey of views}

Language is a means of communication, exchange of information, views, ideas, emotions, feelings, etc. As Slyusareva noted, all the palette of speech act reflects communicative intention of the speaker to inform on thoughts about which listener (recipient) hearing the text should be informed (Slyusareva, 1986). The choice of language means depends on just the aim of our speech, on speech acts which are called communicative strategy. Ivanova and Chernik determine communicative strategy as the "whole of language means and speech methods for the sender to achieve conveying the intended aim of communication". (Ivanova \& Chernik, 2010). Communicative strategy is very dynamic, as in the course of communication, depending on the speech act of the opponent and on the contents this strategy is subjected constantly to corrections. Dynamics of correlation realized at this moment of speech act in comparison with the previous one and also other influence on the following is one of the main signs of manifestation of strategy.

Process of speech, as to Referevskaya, causes the establishment of text-speech production, information developing in the systematic description. They may either be grounded on the basis of the line of a text, or join one of bordering lines, or at last wedged in the type of other information in the flow of speech. These segments of speech in their turn consist of, a series of sentences, linked with one another not only logically but also formally linguistically (Referevskaya, 1983).

On the basis of facts of communication types and kinds of texts, which in different plans differentiate the supposed invariant features of systems (also the features of valency), differ (Stepanova, 1978). 
Consequently, text is the product of speech activity. Speaking on the text it is necessary to note the theory, created by Melchuk under the name of theory of meaning-text. One of the main peculiarities of this theory is the use of syntax depending on the description of syntactic relations. In this matter confrontation of actants and sircostants have great importance. In the frame of theory of meaning-text, syntactic theory is the description of establishment of predicative ground-just the peculiarities of verbal governing (Melchuk, 1999).

\section{Method of Investigation}

In the process of investigation of text-forming potentials of verbs in the English, Russian and Azerbaijani languages comparative-typological and descriptive methods have been used.

\section{Text-Forming Potentials of Verbs}

As it is known, different types of texts exit, such as descriptive, informative and discourse texts. Let's take some examples from literary fictions and consider valent relations of verb with independent words within the text. Example in the English Language,

The scene was a plain, bare, monotonous vault of a schoolroom, and the speaker's square forefinger emphasized his observations by underscoring every sentence with a line on the schoolmaster's sleeve. The emphasis was helped by the speaker's square wall of a forehead, which had his eyebrows for its base, while his eyes found commodious cellarage in two dark caves, overshadowed by the wall. (Dickens, 1995)

He still had at fifty-two a very good figure. As a young man, with a great mass of curling chestnut hair, with a wonderful skin and large deep blue eyes, a straight nose and small ears, he had been the best-looking actor on the English stage. The only thing that slightly spoiled him was the thinness of his mouth. He was just six foot tall and had a gallant bearing. (Maugham, 1979)

In the given examples which are texts-description, direct word order is noted. The usage of compound nominal predicate, both verb in the passive voice, and also verb forms of simultaneous actions make it possible to understand the situation quickly. It once more confirms the necessity of using verbs, and at the same time proves the fact that verb in itself is not a syntactic unit. Here we note the usage of the verbs of 2 valency, which demand after them obligatory actants.

In the Russian language the usage of verb in the text-description a little differs from its usage in the English Language. Let's consider the following passage,

В поле ни речи. Все как будто умерло; вверху только, в небесной глубине, дрожит жаворонок, и серебряные песни летят по воздушным ступеням на влюбленную землю, да изредка крик чайки или звонкий голос перепела отдается в степи. Лениво и бездумно, будто гуляющие без цели, стоят подоблачные дубы, и ослепительные удары солнечных лучей зажигают целые живописные массы листьев, накидывая на другие темную, как ночь, тень, по которой только при сильном ветре прыщет золото. (Гоголь, 1984)

Сквозь камышовую крышу навеса сочился гаснущий свет месяца. Сорвалась и стремительно скатилась к горизонту падучая звезда, оставив на пепельном небе фосфорический стынущий след. В пруду закрякала матерка, с любовной сипотцой отозвался селезень. (Шолохов, 1991)

Here, different from the English language, in the first sentence absence of verb is observed which does not create any difficultly to understand the text. If in the English language we observe direct word order in text-description, but in the Russian language the usage of inversion is one of the means of expressing the description. The usage of verb forms of simultaneous actions here too becomes one of the means of conveying the author's thoughts.

Disposition of verb in the text-description can be observed in the following example in the Azerbaijani language,

Q1̧̧ səhəri idi, soyuq idi və o səhər seyrək qar yağmağa başlamışdı, amma qar yerə düşən kimi, su olurdu, asfaltın üstündə bircə damcı yaş ləkəyə çevrilirdi. (Elçin, 1985)

Hacı Oləkbər Namazov 60-65 yaşlarında, ilk baxışda çox zəif, arıq bədənli, əslində gümrah bir kişi idi. Cır-cındır üst-başı, çoxdan qırxdırmadığı üzünün kələ-kötür tükləri, batmış ovurdu, iti çənəsi, danışarkən üst damağından asılıb qalmış və dilinə toxunmuş tərpənən yeganə iri, sarı dişi onu çox qəribə göstərirdi. (Seyidbəyli, 1988)

Әyninə sırıqlı geymiş üzü tüklü, ortayaşlı bir kişi cibindən yöndəmsiz bir alışqan çıxarıb, damağındakı sönmüş papirosunu yandırdı, sonra alışqanı cibinə qoyub barmă̆ına doladığı narın zənciri hərləməyə başladı. Zəncirin ucunda xırda bir açar var idi. Bu, maşın açarı idi. (Seyidbəyli, 1988) 
In the given examples direct word order is observed, which is the same in English. Construction S-V-O, different from the English and Russian languages, in the Azerbaijani language acquires a little another form, namely, object and subject change their places. In the above-mentioned examples we observe this tendency.

Let's consider the following passages of texts,

No word of a new marriage had ever passed between them; but Rachel had taken great pity on him years ago, and to her alone he had opened his closed heart this time, on the subject of his miseries; and he knew very well that if he were free to ask her, she would take him. (Dickens, 1995)

When they had been in management for three years they were sufficiently well established for Michael to be able to borrow from the bank enough money to buy the lease of a theatre that had just been built. After much discussion they decided to call it the Siddons Theatre. They opened with a failure and this was succeeded by another. (Maugham, 1979)

Martin learned to do many things. In the course of the first week, in one afternoon, he and Joe accounted for the two hundred white shirts. Joe ran the tiler, a machine wherein a hot iron was hooked on a steel spring, which furnished the pressure. (London, 1980)

The given texts are examples to text-narration. Just the usage by the author verb-predicate in the active voice, voice-time forms, underlining the character and alternation of events helps to express the situation distinctly.

In the Russian language examples of text-narrations are as followers:

На следующий день он пришел к Ардашеву в назначенный час. Приветливая пожилая женщина, отворившая дверь, сказала, что Николай Петрович вышел куда-то, но с минуты на минуту должен вернуться. Завтрак уже готов. (Толстой, 1982)

Антуан Риво повесил на крючок шляпу и трость, поджимая живот, кряхтя, пролез к окну и хлопнул ладонью по мраморному столику. Вот уже пятнадцать лет в один и тот же час он появлялся в этом кафе и садился на одно и то же место. (Толстой, 1982)

Днем Мишель Риво бродил по большим бульварам и покупал мелкие, бесполезные предметы, а к часу обеда подавался в рабочие кварталы. Он ел без вкуса, поспешно, иногда прямо на улице. Желудок его был не в порядке. (Толстой, 1982)

As it is seen clearly, narration reveals closely-connected with each-other events, occurances actions, objectively taking place in the past. From the above-mentioned examples we visually observe replacing one-another action verbs of the past tense in the active voice.

In the Azerbaijani language verbs show themselves in the text-narration in the following manner,

Teymur Cahangirov ancaq səhərə yaxın özünə gəldi. Ayılıb gördü ki, şəhərin ucqar məhəllələrinin birindədir. $\mathrm{O}$, başında dözülməz bir ağrı hiss edib inildədi. Qulaqlarında üzücü bir uğultu var idi. Bədəninin ağırlığını sol qoluna salıb güclə səkinin üstündə oturdu, kütləşmiş nəzərləri ilə ətrafa göz gəzdirirdi. (Seyidbəyli, 1988)

Bir dəfə bazardan nar alırdım, məndən irəlidə yaşlı bir qadın da nar alırdı və barmaqları ilə narın bərkliyini-boşluğunu yoxlaya-yoxlaya bir-bir seçib tərəziyə yığırdı. İii "aerodrom” papağını gözlərinin üstünəcən sallamış nar satan oğlan etiraz edirdi. (Elçin, 1985)

The passages once more confirm the thoughts on the fact that in the Azerbaijani language the same systematization of actions as they are in the English and Russian languages, is observed. This or that sentence is logically and grammatically linked with each-other.

It is necessary to note that in the realization of communicative strategy of speech, theme plays an important role, which alongside the rheme are systematic, but functionally not equally communicative components. Theme and rheme as functional-semantic categories, are linked with the establishment of a text and are of much more importance than other units of syntax. The main aim of thematic and rhematic relations is development of information in a certain text. Theme is the initial point of information, its beginning, starting point. Rheme contains information on the theme. The means of disposition of such communicative components, as theme, rheme and contrast and so on makes it possible to add new meanings to the semantics of utterance. Moreover the sentence itself possesses new meanings in its communicative-neutral variant (İvanova \& Chernik, 2010).

The theme of a sentence is expressed by a group of subject, but rheme is expressed by a group of predicate. Many of the linguists think that it is necessary to distinguish the third element of deep structure, namely, a transition 
which appears to be somewhere in the middle, between theme and rheme. Transition occupies periferic place in the rhematic part and usually appears to be a transition (Burlakova, 1984).

During the further development of the theory of deep structure, linguists included a terminology into the linguistics as "communicative dynamism" which as to their opinion, is connected with the fact that functional organization of a sentence can be exactly determined, exposing communicative dynamism. Understanding of communicative dynamism made it possible to more exactly imagine the exposure of functional perspectives of sentences. On the basis of this theory it was suggested to consider the theme by the element or the elements, which carry out the lowest degree of communicative dynamism (Burlakova, 1984).

If we study the sentence examples in the English language, then we see, that the highest degree of communicative dynamism is observed just in the expression of verbs. For example, as in these sentences,

He might have murdered her or stolen her pearl necklace. (Maugham, 1979)

It would save an agent's fees. (Maugham, 1979)

Tom was to go out to town by an early train on Monday morning. (Maugham, 1979)

Sissy resumed in a lower voice. (Dickens, 1995)

But we must meet, my dear Louisa. (Dickens, 1995)

Her eyes sparkled good-naturedly. (London, 1980)

In all the above-mentioned examples communicative importance is characteristic only to the verbs, which bear more important information, than the groups of subjects.

If we pay our attention to the examples in the Russian and Azerbaijanian languages, then practically we shall notice the same results:

Аксинья чему-то смеялась и отрицательно качала головой. (Шолохов, 1991)

Привставая на стременах, Григорий следил за ним, вытирал рукавом слезы, застилавшие нахлестанные ветром глаза. (Шолохов, 1991)

Наталья оделась и пошла из горницы. (Шолохов, 1991)

Эти люди со странными усмешками не глядели ему в лицо. (Толстой, 1982)

Bulvar boyu addımlaya-addımlaya kənardan özüm-özümə baxdım. (Elçin, 1985)

Anam əlində tutduğu şalvarı mənə verdi, əllərini günorta həmişə əynində olan döşlüyünün ətəyinə silə-silə mənə baxd1. (Elçin, 1985)

Anam şalvarımı yudu, həyətdəki zivədən asdı, şalvar o isti payız günəşinin altında tez qurudu. (Elçin, 1985)

As it is obviously seen, the above-mentioned examples possess higher degree of communicative dynamism.

Phenomenon of inversion both in the Russian and Azerbaijani languages is of special interest. Very often theme changing its habitual place, works for the use of rheme, helps to move rheme into accentuated position. One of such strategy is the strategy of "recession" of theme, where thematic component is taken into atonic niche after the initially accentiated and inverted verb. Kovtunova notes the splint of rheme and formation of rhemical accented structure of phrases in the cases when form the composition of predicate, showing itself as a verbal combination, the verb is extracted and is put before the subject, but the word form depending on the verb remains after the verb. For example,

Меркли краски на западной концевине неба, рассасывал ветер тучи. (Шолохов, 1991)

Видел я Елизавету случайно, в окне трамвая. (Шолохов, 1991)

Into his eyes leaped a wistfulness and a yearning as promptly as the yearning leaps into the eyes of starving man at sight of food. (London, 1980)

Never had anything to do with her. (London, 1980)

Побывала старушка у Троицы... (Блок, 1991)

Придет шарманщик хмурый. (Блок, 1991)

Оковала земля окаянная (Блок, 1991)

На бору со звонами плачут глухари (Блок, 1991)

Сыплет черемуха снегом... 
Ходят грачи в полосе. (Блок, 1991)

Let's consider the process of inversion in the Azerbaijani language. We'll introduce the example from the works of well-known Azerbaijani poet S. Vurgun.

Açıldı bir zaman sabahın gözü,

Göründü dağlarda günəşin özü. (Vurğun, 1986)

Susdu səma, susdu dəniz, susdu torpaq,

On addım kənarda yatmayır ləkə,

Gəzinir, oylağa baş çəkə-çəkə. (Vurğun, 1986)

In comparison with the English language, in which partial inversion of sentence members take place and first of all it happens with predicate, in the Azerbaijani language, partial inversion doesn't exist, but there exists exclusively full inversion of compound predicate, namely of the verbs. Despite the fact that formal variant and functional power is less in the Azerbaijani language in comparison with the English language, its role in the deep construction of the sentence, in the emotional semantic accentualization of its meaning, and also stylistic optimal formulation of its word order in different revelation of the thoughts in it is great. Just this importance of inversion determines its widely usage in the Azerbaijani language in the most different communicative types of sentences and in styles of speech.

Reading these lines we once more observe the change of place of the theme from its place and from the accentuated verb. It is necessary to note that "recession" of theme is one of the communicative variants, realization of which takes place only in the condition of prepositioning of the verb. As it is seen, in the above-mentioned sentences, names, time and place are used in the back plan, but action is used in the first plan, accentuating all our attention just to the verb. This is a kind of stylistic effect in itself. Such sentences most of all are met in the Russian tales, in the epic folklore narration and in literary stylization. It is necessary to note, that a sentence with a direct word-order can be used as separately taken information and as a part of context, but a sentence with the preposition of verb, namely, with "tale" word order is not used as separately-taken information, they demand continuation. (Qurbanov, 1989)

Let's see a passage from Russian tale;

Жила-была на свете лягушка-квакушка. Сидела она в болоте, ловила комаров. Весною громко квакала вместе со своими подругами. И весь век она прожила бы благополучно-конечно, в том случае, если бы не съел ее аист. Но случилось одно происшествие.

Сидим мы у окна, вдруг видим -по двору бежит Иваныч, а во рту огромная крыса. Вскочил он в окно-прямо к маме в комнату. Разлегся посреди пола, выпустил крысу, сам на маму смотрит.

Залез Муравей на березу. Долез до вершины, посмотрел вниз, а там, на земле, его родной муравейник чуть виден.

Considering the examples of such type we pay attention to the stylistic and text-forming effect of change of place of verbs. If we compare such sentences with the sentences with neutral disposition, it becomes clear that a sentence with its "tale" word order cannot become separately-taken information and happens to be the beginning of narration, promising the continuation as it is seen in the example Купила Женя себя баранок, where obligatory constinuation is demanded. The given sentence in correct word order can be also a part of the context and a seperately-taken sentence, Женя купила семь баранок.

\section{Conclusion}

Considering the text-forming potentials of verbs in English, Russian and Azerbaijani languages we have come to the following conclusions:

1. Combination of verbs with other words in the sentence is used only for the realization of this or that communicative strategy.

2. Verbs do not only name a concrete action, but they envisage the meaning of the whole situation.

3. Grammatical category of verbs is used not only for composing a text, but they greatly influence on the meaning of statements and texts.

4. Considering the degree of communicative dynamism on the basis of examples in the three languages, it becomes obviously clear that, the highest degree of communicative dynamism is observed just with the verbs, as verbs bear more important information than the group of subjects. 
5. While considering the process of invertion we also notice the movement of the action forward, just the accentuation of the verb.

6. Noting the importance of combination of verbs with other words in the act of communication, namely, widely and all -rounded usage of theory of valency, the correct place of verb in the communicative strategy is determined.

\section{References}

Burlakov, V. V. (1984). The syntactical structure of Modern English. Moscow.

Dickens C. (1995). Hard Times. Wordsworth Classics.

Elçin. (1985). A ̆g dəvə. Bakı, Yazıçı.

Ivanova, O. V., \& Chernik, N. (2010). Communication strategies and their role in the training of specialists in nonlanguage high school.

London, J. (1980). Martin Eden. Kiev: Dnipro Publishers.

Maugham, S. (1979). Theatre. М., Международные отношения.

Melchuk, I. A. (1999). The experience of the theory of linguistic models. The meaning of text. Languages of Russian Culture. Moscow.

Qurbanov, A. M. (1989). Ümumi dilçilik, 1.c. Bakı, Maarif.

Referovskaya, E. A. (1983). Linguistic studies of the structure of the text.

Seyidbəyli, H. (1988). Cabhədən cəbhəyว. Bak1, Gənclik.

Slyusareva, N. A. (1986). Categorical basis of theme-rematical organization of sentence. Questions of Linguistics.

Stepanova, M. D. (1978). Parts of speech and the problem of valence in modern German language.

Vurğun, S. (1986). Seçilmiş asarlari, 3 cilddə. 2-ci cild. B., Azərnəşr.

Блок А., Маяковский В., \& Есенин, С. (1991). Избранные сочинения. М., Художественная литература.

Гоголь, Н. В. (1984). Вечера на Хуторе близ Диканьки. Миргород. М., Художественная литература.

Толстой, А. (1982). Эмигранты. М., Издательство -Правда.

Шолохов, М. А. (1991). Тихий Дон. М. Худож. лит.

http//www. dagdiplom.ru

\section{Copyrights}

Copyright for this article is retained by the author(s), with first publication rights granted to the journal.

This is an open-access article distributed under the terms and conditions of the Creative Commons Attribution license (http://creativecommons.org/licenses/by/3.0/). 